\title{
PROFESSOR WILLIAM GEORGE GRIEVE FORREST ${ }^{1}$
}

\section{(24 SEPTEMBER 192514 OCTOBER 1997)}

MARGARET has asked me to contribute, to this commemoration of George, some sketch of his life and work as teacher and scholar. This I do gladly but with much trepidation, for my closest contact with him was 40 years ago, during his earlier years as a Wadham tutor, while there will be many here today whose memories are more recent or more colourful. In attempting this sketch, I am therefore most grateful to all those who replied to my request for information or anecdotes or evaluations. They are too many to list by name, but the very scale and warmth of their responses reflects a, perhaps the, fundamental fact about him, that he was one of the great Oxford tutors. In saluting him today, therefore, we are not just commemorating a person (though we are fundamentally doing that) but also looking at him as an exceptional exemplar of a distinctive academic tradition which these days is under considerable strain.

Scholars, if they are adult human beings, are not disembodied personae: background and environment help to make them what they are. George's was a productive mixture of very disparate elements. One component, intrinsic to one born in Glasgow, was Scottishness. Outwardly, indeed, it showcd little, for the accent was overlaid, the Douglas tartan and the partisanship for Rangers were not (to us undergraduates) much in evidence, the impressively low golf handicap even less. Inwardly, however, it gave him roots in working-class radicalism, a classlessness, and a sense that the French colleagues with whom he worked in Delphi and Athens were allies rather than competitors. It also gave him the opposite of Scottish primness, an inexhaustible taste for the anarchic and the ridiculous. A second component, however, has to be his upbringing in London from the age of two as the son of Willy Forrest, who in those years was establishing a national reputation as a journalist and war correspondent for the Daily Express and then for the News Chronicle. The cultural influences of Willy's books, languages, and international contacts clearly combined productively enough with education at University College School, Hampstead, to yield a scholarship to New College and eventually a double First. However, a third component intervened in the form of war service as a meteorologist in the RAF, including active service on Omaha Beach in the wake of D-Day. I mention that not so much because he and his father ended up in different roles in the same theatre of war, as because I have had from two sources a strong hint of the depth of the trauma which that exposure to violence and slaughter induced in him. Its effects, I think, stayed with him, as did his resort to coping mechanisms which verged on the self-destructive.

Equally important, however, and infinitely more constructive, was a fourth component, the influence and friendship of four scholars at post-war Oxford: his tutors Tony Andrewes, Peter Fraser, and Tom Brown Stevens, and perhaps above all Maurice Bowra, the man who spotted his ability and offered him a Fellowship at Wadham even before his First in Greats came

\footnotetext{
1. This is the text of an address given in New College Chapel, Oxford, on 7 Feb. 1998 in the course of a commemoration of George Forrest's life and work. It is
}

printed virtually as delivered, with minor improvements suggested by Margaret Forrest, Gerald Cadogan and John Boardman, to whom my thanks. 


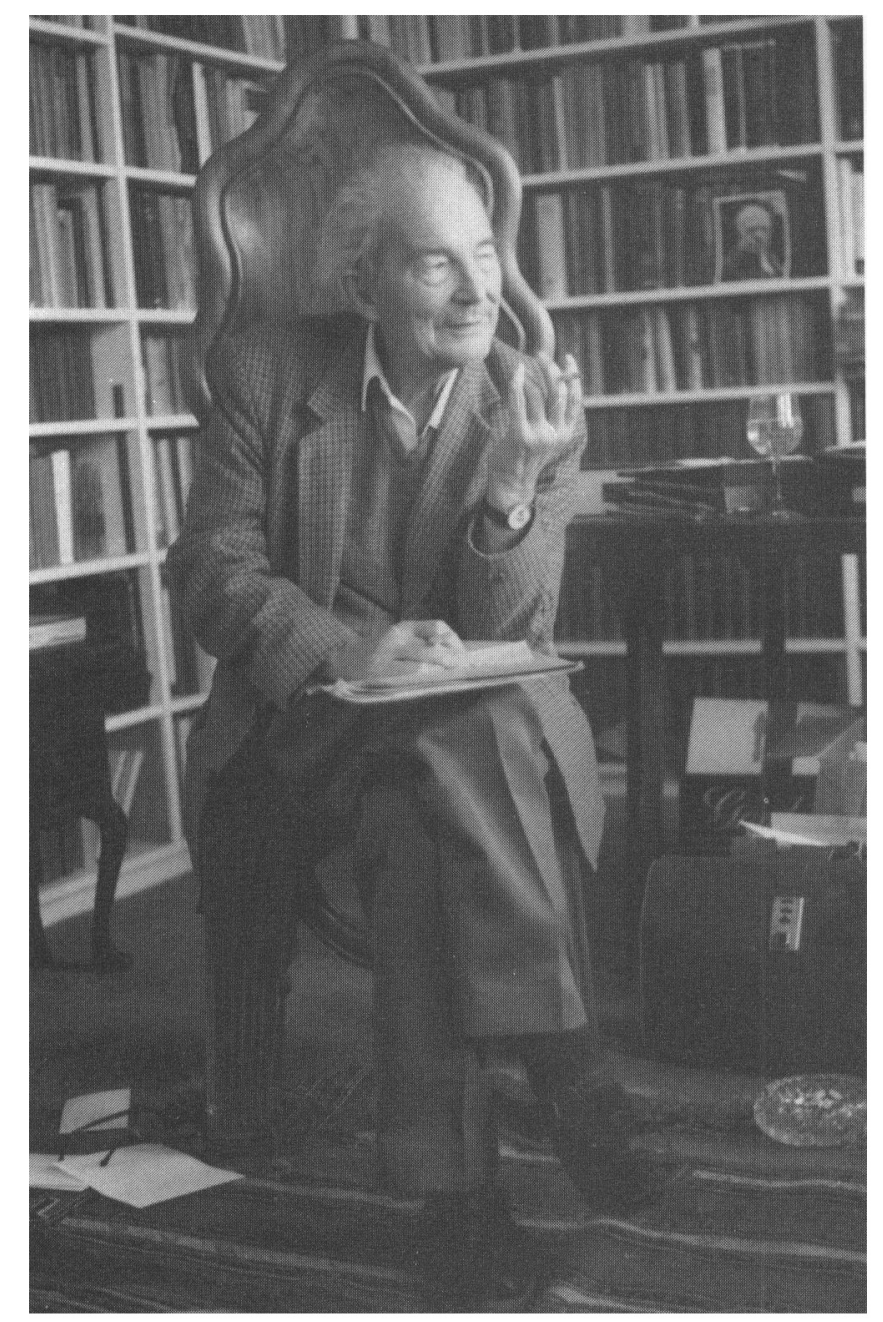

George Iorrest: photograph by Michael Gabricl.

through. In that post he was in his element. Professional skills and knowledge, personal vitality and enthusiasm, the confidence of his mentors, and the slightly bewildered readiness of pupils to respond to strong mixed draughts of Verdi, sherry, unprintablc comments on politicians alive or dead, cigarette smoke, and imaginative but entrancing syntheses of past events, all combined to create a contcxt wherein ancient history was simultancously serious and exhilarating. Fundamentally, we are here today because of what Gcorge created in that chaotic room and in the minds of his pupils.

I shall return to that context in a few minutes, but there are two more dimensions to add. The first, obvious even to us as undergraduates in the Fifties, was a combination of relationships, the contented informality of his personal relations with his Wadham colleagues on the one hand, and on the other the strength, warmth, and security which his family life with Margarct and their daughters gave him. The second was his other love affair, with 
Grecec and its peoples. I do not know whether it was that, though at the other cnd of Europe, Greece with its Highlands and Islands, its slightly embattled sense of nationhood vis-ä-vis a larger neighbour, and its comparative classlessness, was not entirely unlike Scotland. Whatcver the rcason, the modern Greek dimension of his life came to matter just as much as the ancient. It combined with his democratic, anti-authoritarian instincts to make him a formidable public focus of opposition to the Colonels and to give him a secure place in the affections of Grecks of every condition: an affection for which his honorary degree from the University of Athens was a much appreciated formal symbol.

Such a formation, and such security of tenure, could have made of him, in those pre-RAE days, a brilliant tutor but no more. Not so, for a steady stream of articles and reviews began in I954 and did not end, in spite of fearful physical handicap, till I995. Hence, part of my task today is to survey his published work and (so far as we yet can) to place it in perspective. Yes, I do have to begin by rcporting a scnsc of a potcntial not wholly fulfilled, conjoined with regrets for what might have been but never came forth. I am referring here to the two big projects, the Inscriptions of Chios for the $I G$ series and the Commentary on Herodotos which was meant to replace How and Wells. Herodotos, I think, never got far beyond a handful of published articles, though they, and successive lectures and seminars, gave Herodotos a lively and sympathetic reading. I suspect that George may have recognized that a single-handed full-scale commentary was a near-impossible assignment. In the event Book II has needed an expert Egyptologist, while the Persian chapters would have needed an equally expert Achaemenist. In general, indeed, so vast has the industry of books and papers on Herodotos been in the last thirty years, and so fast has the academic discourse on him been transforming itself in that period, that work on a commentary format, by its nature a travail à longue haleine, would have been overtaken several times over before it could be completed.

That, fortunately, is not true of his work on the Chios inscriptions, which began in $195^{2}$. Though not rcquiring a visit every year, it made him an informal member of the British School's Chios team of the I950s, of which legendary équipe so many stories are told, gave him a lifelong love of Chios, and clcarly had a profound influence on his 'reading' of Greece. It was academically productive, too, yiclding cleven published papers which frame his working life from I954 to ig88. They show the other side of George's scholarship, the essential complement of his politically oriented, mainland-based work. Admittedly, they are hard going, for serious epigraphy cannot make many concessions to the casual reader, and George was a very serious epigraphist indeed. Careful reading from stone, squeeze, and photograph; sensitive dating, on the basis of a wide first-hand acquaintance with fashions and letter-forms in Chios and elsewhere; prudent restoration, which avoided the epigraphical equivalent of what Denys Page in a papyrological context once called 'private poetry'; and detailed commentary, which revealed how much effort he had put in to master the relevant aspects of onomastics, or metrology, or the history of ritual and religion, or the institutions and practices of the Acgean communities from the Archaic period to the Byzantine and beyond: all these skills went into the published papers. I suppose we all remember the visible symbol of this work, the squeczes which helped to render the billiard table next to invisible, just as one of my informants recalls George's encouragement to the members of a postgraduate class physically to touch, feel, and even 'fondle' the stones in the Ashmolean. Such terminology sounds over the top, but it is not. You cannot do good epigraphical work unless you have a zest for the intractable thinginess of the stones, for the status of their 'visible words' (in John Sparrow's phrase) as a chaotic fragmentary proto-archive, or for the human and social realities which lie behind and beyond those words. George had that gift in abundance, and though we must 
regret that the volume is still some years away, we can at least be glad that George's main archive of squeezes, photographs, and notebooks is detailed enough to form its substantive basis. Given, too, his exceptional rapport with Greece and Greeks, it is appropriate and welcome that it should be a Greek colleague, Angelos Mathaiou, who has taken over responsibility for the volume. $I G$ xii, 6. I will therefore eventually be Forrest and Matthaiou, and we wish Mr Matthaiou Godspeed in his labours.

From Chios now back to the mainland, and to his first major publications, the two papers of I956 and 1957 on Archaic Delphi. They were exceptional in their maturity, range, and influence, though those of us who read them hot from the press in those years had little idea how revolutionary they were. In contrast to what had till then been essentially antiquarian work on the documents, the buildings, the artefacts, the oracles, and the cult practices, those two papers put the politics back into Delphi, and thereby re-oriented large chunks of Archaic Greek history. Granted, subsequent work has undermined some of his working assumptions, but the basic perception subsists: the oracle functioned as it did because it was needed, not by individuals (as Dodona was), but by communities and rulers who needed divine sanction for awkward decisions, a semi-neutral arena for competitive display, or even a stecr towards survival. Nowadays, of course, to see the passive and active life of sanctuaries as an integral part of the political, as well as of the social, process is common coin: George, that profoundly political animal, deserves high recognition as one of its pioneers.

And yet this recognition of the primacy of the political should be no surprise, for it runs through virtually everything that he wrote. Never more than with his first book, The Emergence of Greek Democracy of 1966 , radical alike for its form and its content. Colloquial to the point where you can virtually hear George speaking as you read it, minimally documented, firmly subversive of established attitudes, and littered with what were then modern instances (some of which have dated rather embarrassingly), it was splendidly unorthodox. But it found an appreciative market, alike in French, Italian, Spanish, and now Greek translations, while, as always with George's written and spoken words, underneath the froth and the intellectual horseplay lay hard scholarly analysis and a serious interpretative message: about democracy ancient and modern, a point he made forcibly in the 1994 preface to the Greek edition, and about how an innovation of seismic importance for subsequent history could have been the product of 'issues [which] . . . may have been far more immediate, far more practical, far more accidental than we who generalise about Greek history are inclined to think they were' (p. I Ig). It is ironic that such a reading should currently be finding its main echoes in those (perhaps less than radical) scholarly circles in the States for whom Greck history is a significant witness in the validation of theories about the state, but it is so. Habent sua fata libelli.

His other libellus, his History of Sparta of 1968 , was more orthodox in form but no less radically constructive in content. It had once been true, as Geoffrey de Ste Croix caustically observed, that 'Books on Sparta are numerous and mostly bad'. They are still numerous, but they are no longer bad: and I do believe that we have George to thank for that transformation. That book, with its accompanying handful of articles, broke the mould. It began to strip Sparta of the layers of fantasy, symbolism, and implausibility which had festooned her for over 2,000 years, and allowed something far more realistic and, dare one say, normal, to appear. Granted, others have both taken the process of normalization further and have brought back into view the exceptional aspects of Spartan society, but so early as I98o, in the preface to the second edition, George could claim that the overall agreement in recent studies prompts confidence. It does not really matter whether Lykourgos existed or not: it does matter that almost all students of Spartan society are now talking about the same kind of 
society' (8, p. 9: cf. also 37). Eighteen years later, that is still true, and as he said, 'that is progress'.

Last in this review of his published works come those on Athenian democracy and on Aristophanes. They are not easy to decode. In part, of course, they take up themes already explored in the Democracy book of 1966 , but there is more to them than that, for their two main focuses are the Old Oligarch and the earlier plays of Aristophanes. Nothing, that is to say, about the nuts and bolts of Athenian administration (still less about the Tribute Lists), but much instead about the politics and about the writers who reflected those politics in wry, jokey, engagé ways. Just as the Old Oligarch could be located in a familiar sort of space as an undergraduate essay written by a lad (called Xenophon?) who was reading PPE with Gorgias (I recall George saying exactly that), so too I think he saw in Aristophanes a deeply kindred spirit-anarchic in temperament, disrespectful of pomp and pseuds, attached to the style and beauty of older writers, standing slightly outside the actual practice of the rough old trade of politics but fascinated by it and its absurdities . just like the cartoonist Vicky, or of course just like Gcorge himself.

All the same, and to be honest about it: limited in quantity and in chronological range, George's list of titles is not an enormous corpus of work. Nothing on Roman history bar a I962 fire-cracker on the Sicilian slave-war written jointly with Tom Stinton, nothing much on the Athenian fourth century, with its documents and its speeches, nothing even, most sadly, on the complex interrelationship between Republican Rome and the Hellenistic powers which he taught so vividly from Polybios. As with all the best tutors, he kncw far more than he wrote. Re-reading the Democracy book, I was struck once more by the imaginative choice of illustrations and by what they reflected, a serious knowledge of at least some aspects of Classical Archaeology. To read his uncharacteristically severe 1958 review of Parke and Wormell on the Delphic Oracle is to realize that he knew his BCH and his Fouilles de Delphes backwards, and with that knowledge came, as one informant has emphasized, 'a tremendously positive and encouraging attitude to Classical Archaeology'. Likewise, though ancient religion, as observance and devotion rather than as a politicized $\Lambda$ pollo, is hardly visible in what he wrote, that did not impede warm personal relations with those who were trying to put religion back into Greek historical scholarship.

However, one major lack of sympathy must be mentioned. It flowed naturally from his and his family's observation of, and participation in, active politics and current affairs, and found expression, both in his writing and (as I remember well myself) in his teaching, in the form of illustrating this turn of ancient events, or that piece of behaviour by a Greek or Roman politician, by means of modern comparisons or analogies. For him, ancient and modern politicians were of the same species, were playing the same kinds of games, and could be characterized in the same analytical language (or the same four-letter words). Augustus was a prig; Delphi was more NATO than UNO; and so on. Not for him the arguments for the deep ineradicable 'otherness' of Greek society, still less for it in French dress as altérité.

That was one limitation. A second, which the obituaries could not entirely pass over, was his administrative unhandiness. I had one personal experience of this myself, and I know of others. It did not prevent him from being a brilliant Dean in the fraught years of the late Sixties, but that was because the art of Deanery in such circumstances was the art of managing a fractious two-hundred-in-hand, not of driving an agenda through an obstreperous committee. Others have judged that this limitation made him a less effective Professor than he should have been, and I am in no position to gainsay that judgement. I think, though, that there was more to it than that. It was partly that he came to be able to work brilliantly in short 
bursts, but not in a sustained way. More basic was that the subject-matter-whether persons, periods, or processes--needed to be congenial before he could give his best, while Romans, Macedonians, the fourth century BC, or non-political history induced antipathy or (worse) boredom. In a way, the epigraphy apart, he had perhaps shot his creative bolt by the time he took on the Wykeham Chair.

His monumentum is thercfore not, regrcttably, a series of volumes of papers edited from thematic seminars, as is the current fashion, nor yet (apart from the as yet unborn Chios volume) the weighty impersonality of a $\mu \varepsilon \gamma \alpha \beta \imath \beta \lambda i o v$. That did not suit his style or temperament. His two books, and his thirty or so papers and chapters, are that monumentum in part, but I would judge that its most important component is rather a series of minds, altered, enlarged, and emboldened by the sort of stimulus and encouragement at undergraduate or postgraduate level which George could provide better than anyone elsc I have known. Some of those minds are here today, and will recall the central icon of that process, what one correspondent has called George's "work-station, the battered armchair surrounded by books and offprints, cigarettes, ashtray and a glass or two'. But that same correspondent gocs on to say: 'It might have been a set designer's stock decor for the absent-minded don, and yet George's teaching style, though informal, was at bottom as rigorous as any I've been exposed to, since one emcrged from his random questioning having been forced to think about, and justify, one's whole approach to whatever it was.' From another source I hear a tale of a man from another college, and from a very different style of teaching, whom George viva'd . . and viva'd . . . and viva'd . . until after two hours he had got the man to think for himself. At which point the man got his First.

No one here will be surprised that such vignettes recur in the profile of him which has come to me from all sides. Explicitly or implicitly, they use the word 'style', in ways which present a superficial paradox. Sartorially, though he could be tidy, even clegant, in subfusc, kilt, or morning dress, his everyday style gave a whole new dimension to the word 'informal'. I recall him lecturing in Wadham clad in an unspeakable sports jacket, flying boots, and mildewed gown which was at once discarded so that he could light a cigarette with propriety: another correspondent reports the story that a little old lady came across him dressed thus in the street, and pressed 5op into his hand, saying 'There there, buy yourself a cup of tea.' Yet he was tidy where it mattered, in his personal integrity and in his scholarship. He exemplified to a surpassing degree the tradition of the scholar who loves his subject and his students, and whose writing cmerges from, and is formed by, the objective of bringing out what is implicit or potential, alike in subject and in pupil. As correspondents have said, 'he taught the person, not the subject': 'he could be a good tutor and a good friend equally to people who weren't his natural friends', politically or religiously or whatever: 'he never made you fecl stupid even when you got things palpably wrong': he could 'aphorize memorably' in person or in print, with one-liners which distilled a decade's teaching experience and transformed one's understanding: but he could also cut through waffle with the direct uncomfortable question 'But look, mate, what do you think they were really aftcr?' That skill, of using the perfectly flighted question in order to make you think the thing out for yourself, may have come his way from Tom Brown Stevens, more remotely from Collingwood and from his idea that a historian is as good as the questions he asks. It made him unique.

Many of us willy-nilly live our lives to a great degree in separate compartments. George chose to minimize that separation, throughout his life. That choice had its downside, for it restricted the range of things he could do. But it also has excmplary value, for it bears witness to two fundamental truths, that you cannot disjoin teaching from research, for they are 
interwoven aspects of the same activity of scholarship, and that you cannot disjoin scholarship from life, for the values of the one must also be the values of the other unless you are to damagc yourself and your students. We are here today to salute that witness. I recall vividly the final sentence of The Independent's obituary of Archbishop Michael Ramsey. It said simply, 'He was loved.' Gcorge was no Archbishop: he was son, husband, father, colleague, Fellow, Dean, and Professor, but above all else a scholar, and with that a tutor and a friend to the young whom he held in such affection. They we return that affection : he too was loved.

University of Liverpool

J. K. DAVIES

\section{GeORgE: FORREST: A BIBIIOGRAPHY}

It has been suggested that a list of George Forrest's publications might be of value to the international scholarly community. The list which follows has accordingly been compiled in order to be subjoined to the address printed above. The initial compilation, by JKD, was scrutinized, emended, and expanded by Margaret lorrest, by Ruth Padel and Noel Worswick as literary executors, and also by Roger Brock, Peter Derow, Steve Hodkinson, Angelos Matthaiou, and Peter Rhodes, to all of whom my warmest thanks. We have tried to ensure that it is complete. Its format follows that of the publications of John M. Cook which was published in this journal in 1997 .

Books

I. Herodotus: History of the Greek and Persian War. Translated by George Rawlinson, edited and abridged with an introduction (pp. vii-xxxviii) by W.G.F. (Washington Square Press, Inc., New York, 1963 : New English Library, London, 1966 ).

2. The Emergence of Greek Democracy: The Character of Greek Politics, 800-400 BC (World University Library, Weidenfeld and Nicolson, London, ig66: McGraw Hill, New York 1966).

3. La Naissance de la démocratie grecque, de 800 à 400 avant Jésus-Christ. French translation of $\mathbf{2}$. by $\mathrm{J}$. Cathelin (Hachettc, Paris, 1966).

4. Le origini della democrazia greca, 800 40o a.C. Italian translation of 2. by V. Mantovani (Il Saggiatore, Milano, ig66).

5. La democracia griega. Spanish translation of 2. (Ed. Guadarrama, Madrid, ig66).

6. De opkomst van de griekse demokratie $800-400$ \%. Chr. Dutch translation of 2, by J. C. B. Esykman (Wereldakademic, W. De Haan J. M. Meulenhoff, s. 1., I966).

7. A History of Sparta 950192 BC: (Hutchinson University Library, London, I968).

8. A History of Sparta 950-192 BC: Sccond, amended edition (Duckworth, London, 1980).

9. A History of Sparta .950-192 Bc: Third edition (Bristol Classical Paperbacks [Duckworth], London, I995).

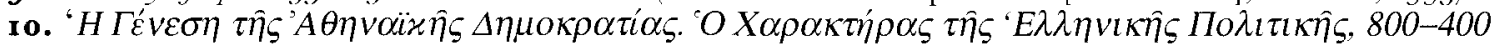

$\pi . X$. Greek translation of 2. by A. Panagopoulos with E. Konti, with additional preface by W.G.F.

(Ekdoseis D. N. Papadema, Athena, I994).

Papers and chapters in journals and edited volumes

I . 'The First Sacred War', BCH 80 (1956), $335^{2 .}$

12. 'A Chian wine-measure', BSA $5 \mathrm{I}$ (1956), $63-7$.

13. 'Colonization and the rise of Delphi', Historia, 6 (1957), 160-75.

14. 'The priesthoods of Erythrai', BCH 83 (1959), 513-22.

5. 'Themistokles and Argos', CQn.s. io (1960), 22I 4I.

16. 'The tribal organization of Chios', $B S A 55$ (1960), 172-89.

17. 'The lirst Sicilian slave-war', Past \& Present, 22 (rg62), 87-93 (with T. C. W. Stinton). 
18. 'Aristophanes' Acharnians', Phoenix, I7 (I963), I-I2.

19. 'The inscriptions of South-East Chios, I', BSA 58 (Ig63), 53-67.

20. 'The date of the Lykourgan reforms in Sparta', Phoenix, I7 (1963), 157-79.

21. "The inscriptions of South-East Chios, II', BSA 59 (I964), 328.

22. 'Some inscriptions of Chios', BSA 6r (I966), i97-206.

23. 'Legislation in Sparta', Phoenix, 21 (1967), I I-I9.

24. 'The tradition of Hippias' cxpulsion from Athens', GRBS Io (I969), 277-86.

25. 'Two chronographic notes', CQn.s. I9 (I969), 95-I Io.

26. 'Alexander's second letter to the Chians', Klio, 5 I (1969), 20I-6.

27. "The date of the pseudo-Xenophontic Athenaion politeia', Klio, 52 (1970), 107-16.

28. 'Aristophanes and the Athenian Empire', in Barbara Levick (ed.), The Ancient Historian and his Materials: Essays in Honour of C. E. Stevens on his Seventieth Birthday (Grcgg International, Farnborough, 1975), 17-29.

29. 'An Athenian generation gap', CClS $_{24}$ (I975), 37-52.

3o. 'Pausanias and 'Themistokles again', $\Lambda \alpha \kappa \omega v t \kappa \alpha i$ ' $\Sigma \pi o v \delta \alpha i$, 2 (Athens, 1975), I 5 - 20.

31. 'Motivation in Herodotus: the case of the Ionian Revolt', International History Review, I (I979), 31 I-22.

32. 'A lost Peisistratid name', JHS 101 (1981), 134.

33. 'An inscription from Chios', BSA 77 (I982), 79-92 (with P. S. Dcrow).

34. 'Euboea and the islands', in $C A H$ iii' $^{2} 3$ (I982), 24960.

35. 'Cicntral Grecce and Thessaly', in $\mathrm{CAH} \mathrm{iii}^{2} 3$ ( $\left.\mathrm{Ig}^{82}\right), 286320$.

36. 'Democracy and oligarchy in Sparta and Athens', EMC 27 (1983), 285-96.

37. 'Herodotos and Athens', Phoenix, $3^{8}$ (1984), I-1 I.

38. 'Some inscriptions of Chios', HOPOE, 3 (I985), 95- 104 .

39. 'Epigraphy in Chios. Cyriac of Ancona to Stephanou', in J. Boardman and C. E. VaphopoulouRichardson (eds), A Conference at the Homereion in Chios $19^{8}{ }_{4}$ (Clarendon Press, Oxford, I986), I33-8.

40. 'Zur Datierung der lykurgischen Reformen in Sparta', German tr. of 2o. by $\Lambda$. Weichenhain in $\mathrm{K}$. Christ (ed.), Sparta (Wissenschaftliche Buchgesellschaft, Darmstadt, I986), 22963.

4I. 'The stage and politics', in M. J. Cropp, E. Fantham, and S. E. Scully (eds), Greek Tragedy and its Legacy: Essays Presented to D. J. Conacher (University of Calgary Press, 1986), 229-39.

42. 'Greece: the history of the archaic period', in J. Boardman, J. Griffin, and O. Murray (eds), The Oxford History of Greece and the Hellenistic World (University Press, Oxford, I986), I3 46.

43. 'A Samian proxeny-decree', HOPO 5 , 5 (1987), 9I-93.

44. 'The Athenian archons: a note', Historia, 36 (1987), 235 40 (with D. L. Stockton).

45. 'An inscription from Lappa', HOPO 2,6 (I988), $6 \mathrm{I}-2$.

46. 'Aristophanes' Lysistrata '23', CQ45 (1995), 240-1.

47. 'The pre-polis polis', forthcoming in R. Brock and S. Hodkinson (eds), Alternatives to Athens: Varieties of Political Organization and Experience in Ancient Greece (Oxford UP).

Places of publication are still being sought for the following :

48. 'Did the battle of Marathon matter?'

49. 'The reforms of Kleisthenes'.

50. 'Comedy and politics' [on Ar. Knights with reference to the Old Oligarch].

5I. 'Polybius xvi 27 : Rome's dealings with Philip V in 202/I' (with N. D. Worswick).

\section{Reviews}

52. P. Amandry, Fouilles de Delphes, ii, Topographie et architecture: La Colonne des Naxiens et le Portique des Athéniens, $7 H S 76$ (1956), $137-8$.

53. H. W. Parkc and D. E. W. Wormell, The Delphic Oracle, i-ii, CR, n.s. 8 (1958), 67-70.

54. R. Crahay, La Littérature oraculaire chez Hérodote, CR, n.s. 8 (1958), 122-4.

55. H. Popp, Die Einwirkung von Vorzeichen, Opfern, und Festen auf die Kriegführung der Griechen im 5. und 4. Jahrhundert v. Chr., CR, n.s. I I (196r), 67-8. 
56. R. Koerner, Die Abkürzung der Homonymität in griechischen Inschriften, CR, n.s. I4 (I964), I I5-16.

57. F. Sokolowski, Lois sacrées des cités grecques: Supplément, CR, n.s. I4 (1964), $3^{19} 20$.

58. F. Kiechlc, Lakonien und Sparta. Untersuchungen zur ethnischen Struktur und zur politischen Entwicklung Lakoniens und Spartas bis zum Ende der archaischen Zeit, JHS 84 (1964), 203-4.

59. L. Dor, J. Jannoray, H. and M. van Effenterre, Kirrha. Étude de préhistoire phocidienne, in $7 H S$ 84 (1964), 206.

6o. J. D. P. Bolton, Aristeas of Proconnesus, JHS 84 (1964), 208- 9 .

6r. J. Pouilloux and G. Roux, Enigmes à Delphes, $7 H S 8_{4}$ (I964), 224.

62. H. Bengtson, Die Staatsverträge des Altertums, ii, CR, n.s. ${ }_{5} 5$ (1965), 329 II.

63. H. Schwabl et al., Grecs et barbares, CR, n.s. I6 (1966), 88-9.

64. R. Flacclière, Greek Oracles, CR, n.s. I6 (1966), $23^{8}$.

65. I. Huber, Religiöse und politische Beweggründe des Handelns in der Geschichtsschreibung des Herodots, Gnomon, $3^{8}(\mathrm{rg} 66), 293^{-5}$.

66. H. Klees, Die Eigenart des griechischen Glaubens an Orakel und Seher, Gnomon, 38 (1966), 628.

67. P. Guillon, Études béotiennes: le bouclier d'Héraclès et l'histoire de la Grèce centrale dans la période de la première guerre sacrée, J̈HS 86 (1966), i 73 .

68. G. Gottlicb, Das Verhältnis der außerherodoteischen Überlieferung zu Herodot, JHS 86 (1966), 185-6.

69. G. Aurelio Privitera, Laso di Ermione: nella cultura ateniese e nella tradizione storiografica, Gnomon, 39 (I967), 828-9.

7o. Ancient Sociely and Institutions: Studies presented to Victor Ehrenberg, CR, n.s. I9 (1969), I95-8.

7r. H. W. Parke, Greek oracles, CR, n.s. I9 (I969), 206-8.

72. T. T. B. Ryder, Koine Eirene: General Peace and Local Independence in Ancient Greece, CR, n.s. I9 (1969), $21 \mathrm{I}-12$.

73. R. Scaley, Essays in Greek Politics, CR, n.s. 19 (1969), 312- I4.

74. C. Mossć, Les Institutions politiques grecques à l'époque classique, fHS 89 (1969), 175-6.

75. D. M. Pippidi, Contributii la storia veche a României, JHS 91 (1971), 198.

76. A. A. Mosshammer, The Chronicle of Eusebius and Greek Chronographic Tradition, CR, n.s. 3I (1981), 77-9.

77. F. Gschnitzer, Ein neuer spartanischer Staatsvertrag und die Verfassung des peloponnesischen Bundes, Gnomon, 53 (I98I), 400 .

78. C. D. Hamilton, Sparta's Bitter Victories: Politics and Diplomacy in the Corinthian War, JHS IoI (I981), 197-8.

79. J. F. Lazenby, The Spartan Army, JHS I07 (1987), 231.

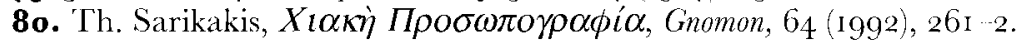

\section{OBITUARIES OF GEORGE FORREST}

r. R. Padel, The Independent, 17 Oct. 1997.

2. P. Derow, The Glasgow Herald, 21 Oct. 1997.

3. [O. Murray], Daily Telegraph, 23 Oct. 1997.

4. N. Worswick, The Guardian, 25 Oct. 1997.

5. [P. Derow], The Times, 29 Oct. 1997.

6. [N. Worswick], Oxford Times, 3 I Oct. I997.

7. P. Derow, Wadham College Gazette, January 1998, 657 .

8. N. Worswick, New College Record, 1997 [1998], 50-2.

9. Anon., Oxford Today, 10.2 (Hilary 1998), 53.

гo. A. Matthaiou, HOPOE, г-12 (1992 8), 61 I-13. 